\title{
CHARACTERIZATION OF SNOW AND ICE REFLECTANCE ZONES ON GLACIERS USING LANDSAT THEMATIC MAPPER DATA
}

\author{
by
}

\author{
D.K. Hall and J.P. Ormsby
}

(Hydrological Sciences Branch, Code 624, NASA/Goddard Space Flight Center, Greenbelt, MD 20771, U.S.A.)

with

\section{R.A. Bindschadler}

(Oceans and Ice Branch, Code 671, NASA/Goddard Space Flight Center, Greenbelt, MD 20771, U.S.A.)

and

\section{H. Siddalingaiah}

(SEA Corporation, 14700 Mentmore Place, Gaithersburg, MD 20878, U.S.A.)

\begin{abstract}
Landsat Thematic Mapper (TM) data have been analyzed to study the reflectivity characteristics of three glaciers: the Grossglockner mountain group of glaciers in Austria and the McCall and Meares Glaciers in Alaska, USA. The ratio of TM band $4(0.76-0.90 \mu \mathrm{m})$ to TM band $5(1.55-1.75 \mu \mathrm{m})$ was found to be useful for enhancing reflectivity differences on the glaciers. Using this ratio, distinct zones of similar reflectivity were noted on the Grossglockner mountain group of glaciers and on the Meares Glacier; no distinct zones were observed on the McCall Glacier. On the TM subscene containing the Grossglockner mountain group of glaciers, $28.2 \%$ of the glacierized area was determined to be in the zone corresponding most closely to the ablation area, and $71.8 \%$ with the location of the accumulation area. Using these measurements, the glacier system has an accumulation area ratio (AAR) of approximately 0.72 . Within the accumulation area, two zones of different reflectivity were delineated. Radiometric surface temperatures were measured using TM band 6 $(10.4-12.5 \mu \mathrm{m})$ on the Grossglockner mountain group of glaciers and on the Meares Glacier. The average radiometric surface temperature of the Grossglockner mountain group of glaciers decreased from $0.9 \pm 0.34^{\circ} \mathrm{C}$ in the ablation area, to $-0.9 \pm 0.83^{\circ} \mathrm{C}$ in the accumulation area.
\end{abstract}

\section{INTRODUCTION}

Glaciers and ice sheets are comprised of an ablation and an accumulation area. Within these areas, several facies are present. Facies display a distinctive group of characteristics that reflect the environment under which the snow or ice was formed. The ablation area consists of exposed ice during the summer and contains the ice facies. The accumulation area can be sub-divided into the wet-snow facies, the percolation facies and the dry-snow facies (C.S. Benson, personal communication). Development of the discrete facies is directly related to the temperature regime and mass balance of a glacier or ice sheet. Net loss by melting occurs in the ice facies. In the wet-snow facies all snow deposited since the end of the previous summer is raised to $0^{\circ} \mathrm{C}$ and wetted by the end of the melt season. The superimposed ice zone consists of a mass of ice which can overlap both the ice facies and the wet-snow facies. The annual increment of new snow is not completely wetted nor does its temperature reach the melting point in the percolation facies. Negligible melting occurs in the dry-snow facies (Benson 1962; Benson and Motyka 1978). At least some of these facies can be detected using Landsat Multispectral Scanner (MSS) and Thematic Mapper (TM) data. In this paper, the use of Landsat TM data for detecting glacier surface conditions and for relating these conditions to the glacier facies is studied through analysis of a glacier group in Austria and two glaciers in Alaska, USA.

\section{BACKGROUND}

The Landsat TM sensor acquires data in seven spectral bands. TM bands 1 through 5 and 7 are in the visible, near-infrared and middle infrared wavelength regions and have a spatial resolution of each picture element (pixel) of approximately $30 \mathrm{~m}$. TM band 6 , a thermal infrared band, is sensitive to infrared surface temperature and has a resolution of $120 \mathrm{~m}$. Spectral reflectivity of snow as determined from the visible, near- and middle-infrared bands is dependent on snow parameters such as grain size and impurity content of the surface layers of the snow (Dozier 1984).

Williams (1983[a], [b], 1987) found that computerenhanced Landsat MSS images were useful for analysis of ice and snow reflectivity differences present on Vatnajökull, an ice cap in Iceland, especially when Landsat MSS data acquired at the end of the summer melt-season were custom processed. In addition, Crabtree (1976) found that Landsat MSS imagery of an outlet glacier, Merkurjökull, of the Mýrdalsjökull ice cap, Iceland, showed a reflectivity boundary that was attributed to differences in glacier surface conditions. There has also been considerable evidence that Landsat MSS data can show the location of the equilibrium line (Hall and Ormsby 1983).

The MSS band $7(0.8-1.1 \mu \mathrm{m})$ is located in a wavelength region which is close to the TM band 4 (0.76$0.90 \mu \mathrm{m})$ region and has been used for detection of surface water on snow and ice (Holmgren and others 1975; Rango and others 1975). TM band 4 has been found by Dozier (1984) to be sensitive to snow grain size and TM band 2 $(0.53-0.61 \mu \mathrm{m})$ to be sensitive to contamination.

\section{STUDY AREAS}

TM digital data of the Grossglockner mountain group of glaciers in the eastern Austrian Alps, the Meares Glacier in the Chugach Mountains in southern Alaska, and the McCall Glacier in the Brooks Range of Alaska, have been analyzed.

The Grossglockner mountain group of glaciers is located 
at approximately $47^{\circ} 10^{\prime} \mathrm{N}, 12^{\circ} 45^{\prime} \mathrm{E}$ in the Noric Alps of Austria. The TM scene (50155-09272) of the Grossglockner group was acquired on 3 August 1984.

The TM scene (50518-20372) of the Meares Glacier in the eastern part of the Chugach Mountains was acquired on 1 August 1985 and is centered at approximately $61^{\circ} 30^{\prime} \mathrm{N}$. $148^{\circ} 30^{\prime} \mathrm{W}$.

McCall Glacier is located in the Romanzoff Mountains of the Brooks Range at $68^{\circ} 19^{\prime} \mathrm{N}, 143^{\circ} 48^{\prime} \mathrm{W}$ in northern Alaska. The McCall Glacier TM scene (50196-20474) was acquired on 13 September 1984.

\section{RESULTS}

TM band $4 \quad(0.76-0.90 \mu \mathrm{m})$ was found to show the greatest variability of the 6 reflective bands, in spectral response in the glacierized areas. Much of the TM band 4 variability in spectral response is caused by snow grain size difference in the accumulation area of the glaciers, and melting or refrozen, previously melted snow. The spectral response pattern of TM band $2(0.52-0.60 \mu \mathrm{m})$ generally follows that of TM band 4 but detector saturation is more common in band 2 over snow-covered areas. TM band 5 $(1.55-1.75 \mu \mathrm{m})$ is quite useful for distinguishing between clouds and snow, and also shows subtle surface reflectivity differences on the glaciers. TM band $6(10.4-12.5 \mu \mathrm{m})$, the thermal band, is useful for measuring radiometric surface temperature and detecting high cirrus clouds over snow and ice.
Using the computer compatible tapes (CCTs), the contrast between imaged features can of ten be enhanced by band ratioing (Moik 1980). This technique is particularly useful in eliminating the intensity variations caused by shadows. The ratio of $\mathrm{TM}$ band 4 to $\mathrm{TM}$ band 5 produces an image product that enhances snow and ice features because of the large difference in spectral response in snow and ice features between band 4 where high digital numbers (DNs, a measure of spectral reflectance) are common and band 5 where low DNs characterize snow and ice. Contrast enhancement is especially evident in the accumulation area of the glaciers, where the difference between the TM band 4 and 5 spectral response is the greatest.

\section{Grossglockner mountain group of glaciers}

Observations of TM imagery and transects across the Grossglockner mountain group of glaciers using TM bands 2, 4 and 5 digital data from CCTs reveal that there are three separate zones in which spectral reflectivity is distinctive. These zones relate to differences in snow and ice surface conditions, e.g. presence of surface water and differences in snow grain size. Fig.1 is an image processed by employing the $\mathrm{TM}$ band $4 / 5$ ratio and assigning colors according to ranges of DNs as seen in Table I. Zone I is within the ablation area or ice facies and may be underestimated due to the similarity in DN between the debris-covered margin of the ice facies and the background. The snow line delineates the ablation area from Zone II

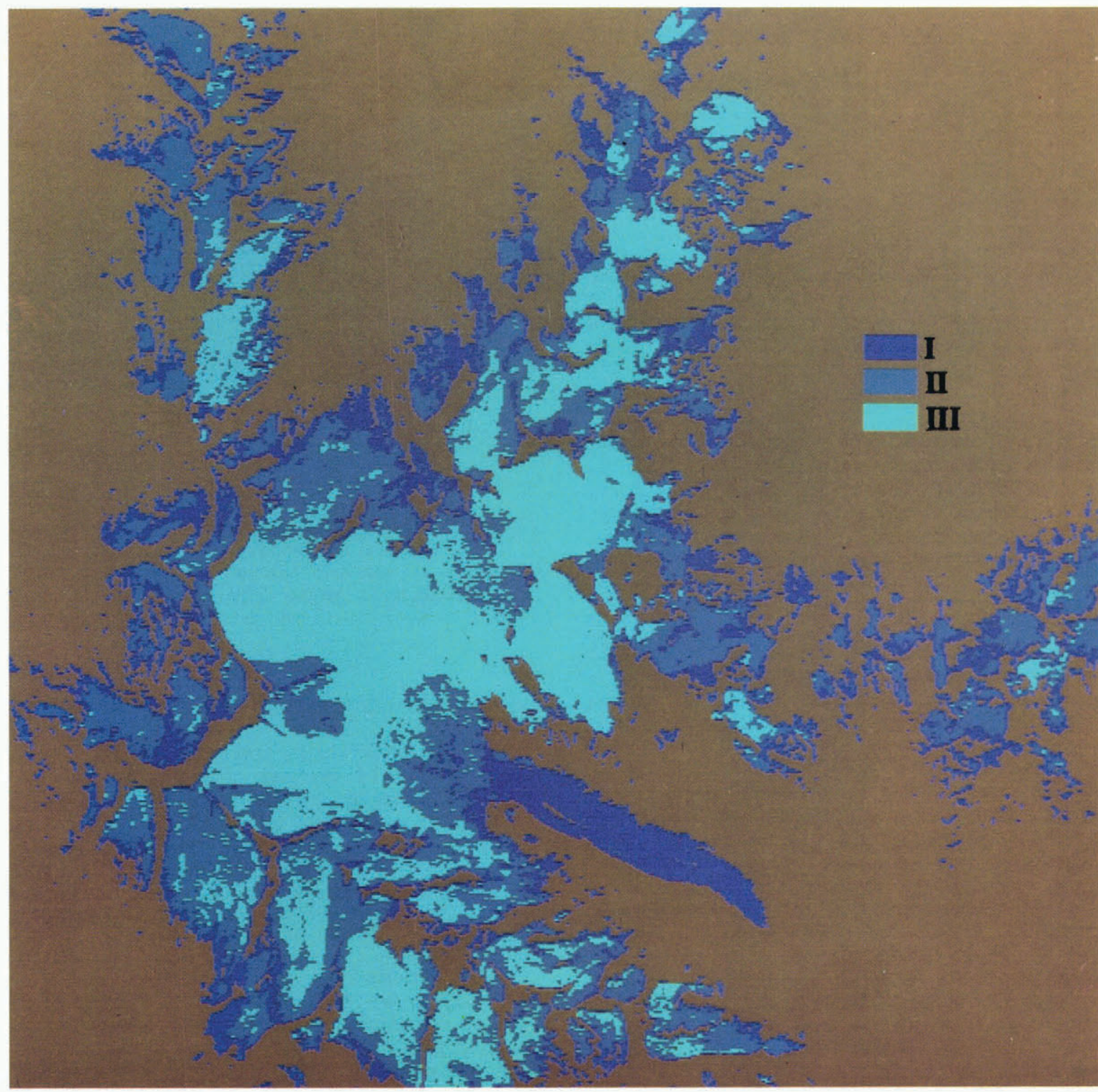

Fig.1. Image obtained from ratioing TM bands 4 and $5(4 / 5)$ and assigning colors to reflectance zones of the Grossglockner mountain group of glaciers; Landsat TM image (50155-09272) was acquired on 3 August 1984. Zone I is believed to correspond to the ablation area and Zones II and III are within the accumulation area. 
TABLE I. STATISTICS FOR THE GROSSGLOCKNER MOUNTAIN GROUP OF GLACIERS USING THE TM BAND 4/5 RATIO

\begin{tabular}{|c|c|c|c|c|c|c|}
\hline Zone & $\begin{array}{l}\text { Number of } \\
\text { pixels }\end{array}$ & $\begin{array}{l}\text { Mean } \\
\text { DN }\end{array}$ & $\begin{array}{l}\text { Range } \\
\text { of DN }\end{array}$ & $\begin{array}{l}\text { Standard } \\
\text { deviation }\end{array}$ & $\begin{array}{l}\text { Area in } \\
\mathrm{km}^{2}\end{array}$ & $\begin{array}{l}\text { Percent } \\
\text { area }\end{array}$ \\
\hline I & 24270 & 106.4 & $73-144$ & 21.02 & 21.84 & 28.18 \\
\hline II & $35 \quad 595$ & 190.3 & $145-226$ & 23.61 & 32.04 & 41.34 \\
\hline III & $26 \quad 239$ & 244.8 & $227-255$ & 9.31 & 23.61 & 30.48 \\
\hline
\end{tabular}

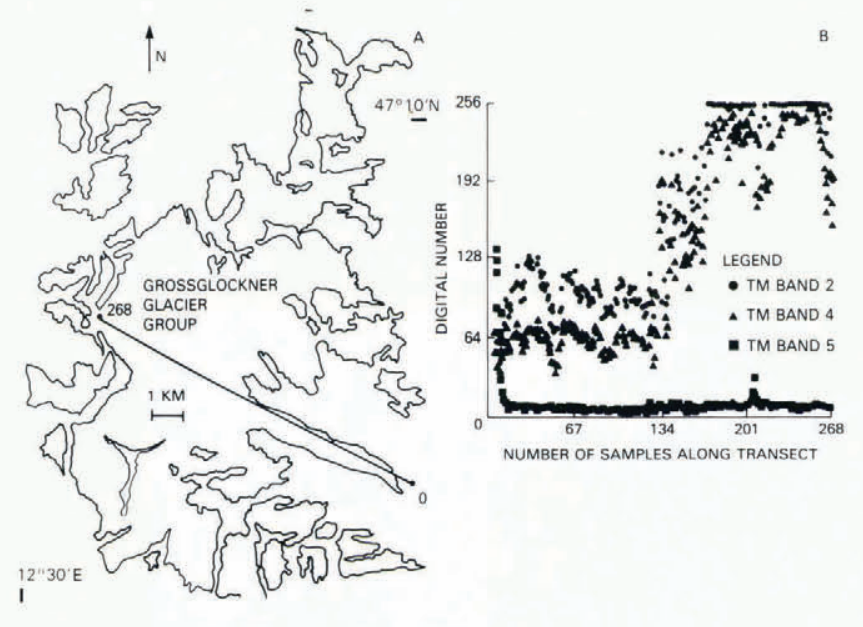

Fig.2. The location of the transect is shown in A. The DNs which correspond to spectral reflectance are shown in B for the Grossglockner mountain group of glaciers; Landsat TM image (50155-09272) was acquired on 3 August 1984.

which is believed to represent some or all of the wet-snow facies. This is quite possibly an area of slush. Zone III may be an area of fresh snow as there was a late-season snowfall in the higher elevations of these mountains $(H$. Rott, personal communication). The small crystals characterizing fresh snow are highly reflective in TM band 4.

A transect across the Grossglockner mountain group of glaciers using TM bands 2, 4 and 5 is shown in Fig.2. Note that some detector saturation occurs in TM bands 2 and 4. In Fig.2B the relatively low DNs for TM band 4 in the ablation area are due to actively melting ice on the glacier tongue, while the highest DNs correspond to that portion of the accumulation area in which the snow that overlies the glacier ice was apparently new at the time of the overpass. A small increase in reflectivity upglacier can be seen in TM band 5 data with DNs being the highest toward the end of the transect near the highest portions of the glacier system.

Histograms showing the frequency of occurrence of each DN for TM bands 4 and 5, for the Grossglockner mountain group of glaciers are shown in Figs 3 and 4 , respectively. In Fig.3, Zones I and III are clearly distinguishable from other features. Zone II appears more as a transition region with no obvious central peak. On the TM band 5 histogram (Fig.4) the snow and ice are shown to have very low reflectivities (DN $\leqslant 30)$ and low variability in reflectivity.

The number of pixels comprising each zone as shown in Fig.1 was determined (Table I). Note that the largest surface area in the Grossglockner mountain group of glaciers is comprised of Zone II. It is important to note that the range of DN selected to delineate each zone

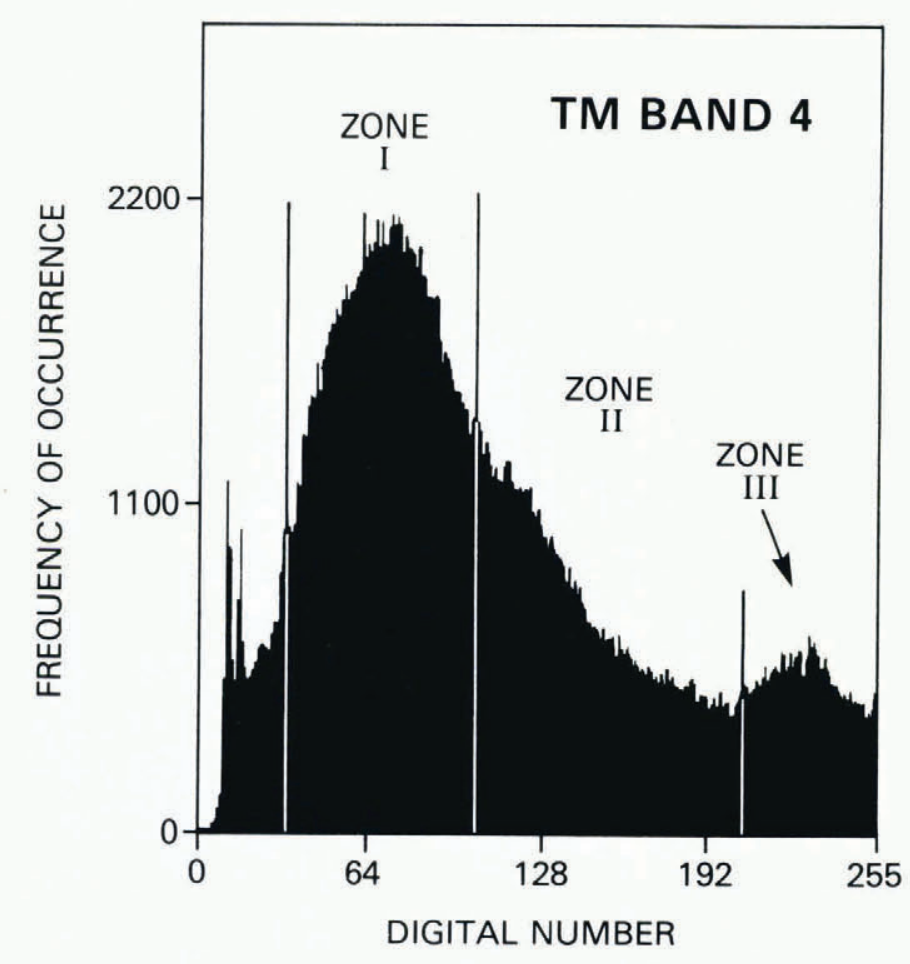

Fig.3. Histogram showing the frequency of occurrence of each DN for TM band 4 of the Grossglockner mountain group of glaciers; Landsat TM image (50155-09272) was acquired on 3 August 1984.

governs the boundaries and thus the percentage area in each zone.

The accumulation area ratio (AAR), the accumulation area divided by the area of the entire glacier, is 0.72 as calculated roughly for the Grossglockner mountain group of glaciers from the data given in Table I. An AAR of about 0.70 corresponds to a net mass balance of zero for temperate mountain glaciers (Paterson 1981). (The fact that the TM data were acquired on 3 August 1984 instead of at the end of the melt season makes the calculation of AAR less precise.)

\section{Meares Glacier}

Using the 1 August 1985 TM data, Meares Glacier shows two distinct areas of similar reflectivity which appear to correspond to the ablation area (ice facies) and a portion of the wet-snow facies. Fig.5 shows a transect across the Meares Glacier. The variability in spectral reflectance in TM bands 2 and 4 in Fig.5B in the central part of the transect results from an icefall in Meares Glacier in which crevassing is present. On this subscene there is apparently no snow present that could be considered to be new. 
The reflectivity differences between the ablation and accumulation areas are pronounced. Within the accumulation area, two zones can be delineated spectrally on the Grossglockner mountain group of glaciers. Extensive surface melt on the McCall Glacier may have caused the reflectance to be similar over much of the glacier surface. In addition, glacier radiometric surface temperatures which are pertinent to the development and distribution of the facies have been calculated using TM band 6 data for the Grossglockner mountain group of glaciers and the Meares Glacier.

\section{ACKNOWLEDGEMENTS}

The authors would like to thank Dr Carl S. Benson of the Geophysical Institute of the University of Alaska, and Dr Richard S. Williams, Jr of the US Geological Survey in Reston, VA, for their reviews of this paper; Dr John Barker of NASA/GSFC for his comments on the calculation of surface temperature using TM data; and Dr Helmut Rott of the Institut für Meteorologie und Geophysik, Innsbruck, Austria for his comments on conditions of the Grossglockner mountain group of glaciers during the summer of 1984.

\section{REFERENCES}

Benson C S 1962 Stratigraphic studies in the snow and firn of the Greenland ice sheet. US Army Snow, Ice and Permafrost Research Establishment. Research Report 70

Benson C S, Motyka R J 1978 Glacier-volcano interactions on Mt. Wrangell, Alaska. Fairbanks, AK, University of Alaska. Geophysical Institute (Annual Report 1977-78)

Crabtree R D 1976 Changes in the Mýrdalsjökull ice cap, south Iceland: possible uses of satellite imagery. Polar Record 18(112): 73-76

Dozier J 1984 Snow reflectance from Landsat 4 thematic mapper. IEEE Transactions on Geoscience and Remote Sensing GE-22: 323-328

Dozier J, Warren S G 1982 Effect of viewing angle on the infrared brightness temperature of snow. Water Resources Research 18(5): 1424-1434

Hall D K, Ormsby J P 1983 Use of SEASAT synthetic aperture radar and LANDSAT multispectral scanner subsystem data for Alaskan glaciology studies. Journal of Geophysical Research 88(C3): 1597-1607

Holmgren B, Benson C, Weller G 1975 A study of the breakup on the Arctic slope of Alaska by ground, air and satellite observations. In Weller $\mathrm{G}$, Bowling $\mathrm{S}$ A (eds) Climate of the Arctic. Proceedings of the Twenty-Fourth Annual Alaska Science Conference, August 15-17, 1973. Fairbanks, AK, University of Alaska: 358-366

Moik J G 1980 Digital processing of remotely sensed images. Washington, DC, NASA Scientific and Technical Information Branch (NASA SP-431)

Paterson W S B 1981 The physics of glaciers. Second edition. Oxford etc, Pergamon Press

Rango A, Salomonson V V, Foster J L 1975 Employment of satellite snowcover observations for improving seasonal runoff estimates. In Rango A (ed) Operational applications of satellite snowcover observations. Washington, DC, National Aeronautics and Space Administration: $157-174$

Schott J R, Volchok W J 1985 Thematic mapper thermal infrared calibration. Photogrammetric Engineering and Remote Sensing 51(9): 1351-1357

Wendler G, Benson C, Fahl C, Ishikawa N, Trabant D, Weller G 1975 Glacio-meteorological studies of McCall Glacier. In Weller $\mathrm{G}$, Bowling $\mathrm{S} \mathrm{A}$ (eds) Climate of the Arctic. Proceedings of the Twenty-Fourth Annual Alaska Science Conference, August 15-17, 1973. Fairbanks, AK, University of Alaska: 334-338

Williams $\mathrm{R}$ S Jr 1983[a] Remote sensing of glaciers. In Manual of remote sensing. Second edition. Falls Church, VA, American Society for Photogrammetry and Remote Sensing: $1852-1868$

Williams R S Jr 1983[b] Satellite glaciology of Iceland. Jökull 33, 1982: 3-12

Williams R S Jr 1987 Satellite remote sensing of Vatnajökull, Iceland: a review. Annals of Glaciology 9: $127-135$ 